\title{
Physico-chemical and Nutraceutical Characterization of Selected Indigenous Guava (Psidium guajava L.) Cultivars
}

\author{
Ali Asad YOUSAF ${ }^{1}$, Kashif Sarfraz ABBASI ${ }^{1 \star}$ (D), Asif AHMAD ${ }^{1}$, Imran HASSAN², Asma SOHAIL ${ }^{1}$, \\ Abdul QAYYUM ${ }^{3}$, Muhammad Aaqib AKRAM ${ }^{1}$
}

\begin{abstract}
In order to ascertain physicochemical and nutraceutical attributes, indigenous guava (Psidium guajava L.) cultivars were comprehensively characterized. Eight cultivars namely Gola, Chota Gola, Surahi, Choti Surahi, Sufaida, Sdabahar, Lal Badshah and Karela were selected due to their climatic adaptability and commercial suitability. All the cultivars showed significant variations in terms of their studied quality attributes. Amongst physical characteristics, Gola exhibited highest $\left(79.9 \mathrm{~mm}^{3}\right)$ GMD with lowest $\left(50.3 \mathrm{~mm}^{3}\right)$ was estimated in Choti Surahi. Insignificant varietal differences were observed in most of the proximate parameters as well as in mineral contents. Nutraceutical estimations showed significant variation in ascorbic acid (222.26-289.43 mg/100 g), total phenolic contents (94.06-190.64 mg GAE/100 g), total flavonoid contents (81.30-154.19 mg QE/100 g) and radical scavenging activity $(27.70-78.15 \%)$ in the selected cultivars. A highly significant correlation $\left(\mathrm{R}^{2}=0.9970 p<0.05\right)$ was observed between ascorbic acid and radical scavenging activity. In sensory evaluation, Gola received over all maximum scores (8.8) amongst its counterparts. Processed data were then analyzed using Principal Component Analysis (PCA) and Hierarchical Cluster Analysis (HCA). The combination of PCA and HCA yielded in a sufficient discrimination of the examined guava cultivars. In PCA analysis, first two PCA components explained $65.98 \%$ of the total variation. Dendrogram successfully classified the tested cultivars into three major groups featuring dissimilarities amongst the cultivars. Research outcome will provide baseline for the farmers, researchers, exporters and other stalk holders to realize the ultimate potential of indigenous guava cultivars for their appropriate commercial utilization.
\end{abstract}

Keywords: guava cultivars; nutraceutical characterization; principal component analysis.

Practical Application: Varietal characterization along with possible value addition

\section{Introduction}

Guava (Psidium guajava L.) a member of Mytraceae family is an important commercial fruit crop of tropics. Archeological studies revealed South American countries as its origin and from there it migrated to Asia (Rodríguez et al., 2010). It is estimated that the World annual production of guava is about 6.8 million tons (Food and Agricultural Organization of the United Nations, 2017); with India and Pakistan shared around 50 percent of the total world production (Yahia, 2018). Brazil, Mexico, Venezuela, Egypt, Sudan, Indonesia, Bangladesh and Vietnam are the other major guava producing countries (Mehmood et al., 2014). Amongst fruit crops of Pakistan, guava occupies $3^{\text {rd }}$ position after citrus and mango with the annual production of 0.586 million tones and carries biannual bearing (Government of Pakistan, 2018).

As "poor man's apple of tropics" guava truly happens to be the fruit for masses in terms of its commercial availability (Hassan et al., 2012). Nutritionists often characterize it under "super-fruits" owing to its diversified bioactive compounds and remarkable antioxidant activity (Joseph \& Priya, 2011). In addition, it can offer four times more vitamin-C than an orange (Hassimotto et al., 2005). Pharmacological studies proved its antidiarrheal, antidiabetic, antimicrobial, hepatoprotective, anti-allergic, anti-plasmodia, anti-spasmodic, anti-inflammatory activities and found equally effective in cardiovascular disorders (Gupta et al., 2018; Upadhyay et al., 2019). An average guava fruit carries $83 \%$ water contents, $15 \%$ carbohydrates, $2.58 \%$ protein, $2.8-5.5 \%$ crude fiber, $0.6 \%$ fat and $0.7 \%$ ash. The fruit is also a significant source of micronutrients like; calcium (23 mg/100 g), phosphorous (42 mg/100 g), Iron $(0.09 \mathrm{mg} / 100 \mathrm{~g})$, Vit. C $(250-300 \mathrm{mg} / 100 \mathrm{~g})$ and Vit. A (200-400 IU/100 g) (Kadam et al., 2012; Flores et al., 2015). Guava is generally consumed as a fresh fruit; however, multiple value added products; as jelly, jam, juices, guava leather, wine, freeze-dried and dehydrated slices are also being prepared on industrial scale.

Being a climacteric commodity, guava fruit carries active metabolism, high respiration rate and limited storage stability at ambient temperature. Physiological processes are regulated by a natural growth hormone known as ethylene which is produced from L-methionine via 1-aminocyclopropane-1-carboxylic 
acid (ACC) synthase in a complex signal transduction pathway (Rueda, 2005). Resultantly, guava fruit attains its climacteric perishability between four to five post-harvest days depending on the variety, harvest time and storage conditions. Reduced postharvest storage life limits options for the commercialization of this important fruit in local and export market.

In Pakistan, different commercial guava cultivars like; Gola, Chota Gola, Surakhi, Choti Surakhi, Sufaida, Karela, Baidana, Ramzani, Surkha, Lal Badshah, Sdabahar, Selection 313, Hafsi etc. are available in the market (Mehmood et al., 2014). Nevertheless, detailed information regarding their physio-chemical and nutraceutical characterization is scanty. Characterizations of fruit cultivars based on physicochemical, biochemical and nutraceutical attributes have marketable significance in defining their intended commercial utilization (Ulhaq et al., 2013; Kyriacou et al., 2020). Furthermore, physico-chemical assessments are also imperative for packaging, consumer acceptability and transportation. Keeping in view nutritional and health-promoting properties, it can also be utilized for the development of different nutraceutical products (Ho et al., 2012). The growing mandate for fresh fruit consumption and export potentials can only be achieved through comprehensive varietal characterization and reduced post-harvest losses. Different plant breeding programs with a focus of developing nutrient-rich cultivars are also being designed to fulfill specific technological purposes. Therefore, the aim of this study was to explore physical, biochemical and nutraceutical properties of indigenous guava cultivars, so as to offer baseline data for the farmers, researchers, marketing and processing entrepreneurs.

\section{Materials and methods}

The presented scientific investigations were carried out at the Institute of Food \& Nutritional Sciences (IF \& NS), PMAS-Arid Agriculture University, Rawalpindi-Pakistan.

\subsection{Collection of Guava cultivars}

Different indigenous Guava cultivars namely Gola, Chota Gola, Surahi, Choti Surahi, Karela, Lal Badshah, Sdabahar and Sufaida were collected from the Horticulture Research Institute, Ayub Agriculture Research Institute, Faisalabad (Pakistan). The fruits were sorted, graded and subsequently precooled to remove the field heat. The representative fruit samples were carefully transported to IF \& NS under controlled conditions ( $85 \%$ relative humidity and $24^{\circ} \mathrm{C}$ ) for further analysis.

\subsection{Physico-chemical attributes}

Physical characteristics of Guava cultivars were measured according to the standard scientific protocols. Digital Vernier caliper was used to measure the size $(\mathrm{mm})$ of the fruits in terms of linear dimensions. Geometric Mean Diameter (Dg) was calculated by using the following Equation (1) as described by Abbasi et al. (2016).

$D g=(L W T)^{0.333}$
Where, $\mathrm{L}$ is the length; $\mathrm{W}$ is the width and $\mathrm{T}$ is thickness of the fruit.

Surface area (S) in $\mathrm{mm}^{2}$ was determined according to the following formula (2) as descried by Baryeh (2001).

$S=\pi D g^{2}$

Sphericity of fruit samples was determined by the following formula (3) as described by Ahmadi et al. (2008).

$\hat{O}=(D g / L) \times 100$

The specific gravity of different guava cultivars were determined by taking the weight of the fruit in air and water according to the following equation (4) as per AOAC (Association of Official Analytical Chemists, 2005) method no. 936.13.

Specific Gravity $=$ Weight in air / (Weight in air - Weight in water $)(4)$

Total soluble solids (TSS) expressed as ${ }^{\circ}$ Brix were determined in the pulp of each fruit sample using a digital refractometer PAL-3 (ATAGO, Japan) as described by Sinha \& Sinha (2017). The $\mathrm{pH}$ values were measured by using digital pH meter (HI 2211 HANNA-USA) calibrated with standard buffers as elaborated by Shetgar et al. (2017). Titratable acidity was determined by titrating $5 \mathrm{ml}$ of juice with $0.1 \mathrm{~N} \mathrm{NaOH}$ and results were expressed as percentage of Malic acid on fresh weight basis (Association of Official Analytical Chemists, 2005; method no. 942.15). Similarly, total sugars were determined by Lane and Eynon method using Fehling's solution as reported in AOAC (Association of Official Analytical Chemists, 2005) method no. 968.28.

\subsection{Proximate composition}

Moisture percentage was determined by oven drying method until constant weight (Association of Official Analytical Chemists, 2005; method no. 930.15), while crude fat estimation was carried out by using ST 243 Soxtec solvent extraction system (FOSS, Denmark) according to AOAC (Association of Official Analytical Chemists, 2005) method no. 930.09. Crude protein was measured by following AOAC (Association of Official Analytical Chemists, 2005) method no. 977.02 through FOSS Kjeltec 8400 Analyzer Unit, Denmark. Similarly, crude fiber and ash content were also analyzed according to AOAC (2005) method nos. 978.10 and 930.05 respectively.

\subsection{Nutraceutical attributes}

Extraction was carried out by taking a homogenous chopped fruit sample (20 g) with $80 \%$ methanol (80:20 methanol-water $\mathrm{v} / \mathrm{v}, 200 \mathrm{ml}$ ) in $500 \mathrm{ml}$ conical flasks and then shaked for $24 \mathrm{hrs}$ at room temperature in an orbital shaker. All extracts were separated from the residues by filtering through Whatman No.1 filter paper and concentrated by using rotary evaporator under reduced pressure (40-50 torr) at temperature of $45^{\circ} \mathrm{C}$ 
(Gull et al., 2012). The concentrated extracts were weighed and stored at $-4{ }^{\circ} \mathrm{C}$ until used for nutraceutical analysis.

Total phenolic contents (TPC) were quantified through Folin-Ciocalteu reagent as per method explained by Gull et al. (2012). The concentrated extract $(0.5 \mathrm{ml})$ was taken in $25 \mathrm{ml}$ volumetric flask to which $5 \mathrm{ml}$ Folin-Ciocalteu reagent $(2 \mathrm{~N})$ and $4 \mathrm{ml}$ freshly prepared $7.5 \%$ sodium carbonate solution were added and the total volume was made up with $80 \%$ methanol. The absorbance at $765 \mathrm{~nm}$ using a CE-2021, Spectrophotometer (CECIL Instruments Cambridge, England) was noted after one hour. Standard gallic acid solutions with varying concentrations (50-450 ppm) in methanol were prepared to draw calibration curve. Quantification of total phenolic contents was carried out as milligrams of gallic acid equivalents (GAE) per $100 \mathrm{~g}$ on dry weight basis.

Total flavonoid compounds (TFC) were measured by the method reported by Gull et al. (2012). One $\mathrm{mL}$ of the aqueous extract was placed in a $10 \mathrm{ml}$ volumetric flask, along with distilled water $(5 \mathrm{~mL})$ followed by $5 \% \mathrm{NaNO}_{2}(0.3 \mathrm{~mL})$. After $5 \mathrm{~min}$, $10 \% \mathrm{AlCl}_{3}(0.6 \mathrm{~mL})$ was added to the mixture. After another $5 \mathrm{~min}, 1 \mathrm{M} \mathrm{NaOH}(2 \mathrm{~mL})$ was added and the total volume was made up with distilled water. Standard Quercetin solutions with varying concentrations (50-450 $\mathrm{ppm}$ ) were prepared for calibration curve and absorbance was recorded at $510 \mathrm{~nm}$ using UV-visible spectrophotometer. TFC were expressed as milligrams of Quercetin equivalents (QE) per $100 \mathrm{~g}$ of sample on dry weight basis.

The stable radical 2, 2-dipheny 1-1-picryl hydrazyl (DPPH) was used for determination of radical scavenger activity (RSA) expressed as antioxidant activity of the extracts by following the method of Verma et al. (2018). According to the method, $3.9 \mathrm{~mL}$ of $0.1 \mathrm{mM} \mathrm{DPPH}$ was added in $0.1 \mathrm{ml}$ of fruit extract. After $30 \mathrm{~min}$ at room temperature, the absorbance was recorded at $517 \mathrm{~nm}$. The percentage of scavenging activity was calculated as the ratio of the absorption of the sample reactive to the control (0.1 mM DPPH solutions without the extract). Radical scavenging activity was measured by using the following formula 5 .

Radical scavenging activity $(\%)=100 \times\left(A_{\text {control }}-A_{\text {sample }}\right) / A_{\text {control }}$

Where $\mathrm{A}_{\text {control }}$ and $\mathrm{A}_{\text {sample }}$ are absorbance of control and sample, respectively.

Vitamin C content (Ascorbic Acid) was determined by titrimetric method using 2, 6-dichlorophenol indophenol (Redox dye) as described by AOAC (Association of Official Analytical Chemists, 2005) method No. 967.21.

\subsection{Mineral composition}

The mineral contents of guava cultivars were determined according to AOAC (Association of Official Analytical Chemists, 2005) method no. 2015.06. The oven dried fruit samples $(1.0 \mathrm{~g})$ were first digested using wet digestion method. Calcium (Ca), Iron (Fe), Zinc (Zn), Manganese (Mn), Copper (Cu), Nickel $(\mathrm{Ni})$ and Magnesium $(\mathrm{Mg})$ were determined in an Atomic Absorption Spectrophotometer (GBC-932 Australlia) whereas Sodium $(\mathrm{Na})$ and Potassium $(\mathrm{K})$ by Flame Photometer
(Model PFP 7 Jenway, England) and Phosphorus (P) by using a Spectrophotometer (CE-2021, 2000 series CECIL Instruments Cambridge, England).

\subsection{Sensory evaluation}

Sensory evaluation of different guava cultivars was conducted by using 9-point hedonic scale as described by Amerine et al. (2013). A panel of trained judges was selected to record their observations in terms of scores for color, aroma, taste and texture attributes.

\subsection{Statistical analysis}

Data obtained after characterization of guava cultivars involving multiple traits was analyzed by different statistical tools. Statistical difference in mean values was compared by Tukey's HSD test using STATISTIX 8.1 (USA) data analyzing software and interpreted according to Steel et al. (1997). Principal component analysis (PCA) was performed by using Addinsoft XLSTAT Pearson Edition version 2015.5.01 software. Pearson correlations were also used to correlate the biochemical characters. The cumulative data from the quantitative and qualitative attributes was used for dendrogram (HCA) construction by following Ward's method.

\section{Results and discussion}

\subsection{Physico-chemical analysis}

The results pertaining to physicochemical characterization of eight indigenous guava cultivars are shown in Table 1 which shows significant variability amongst the tested attributes. However, fractional significant difference was found regarding $\mathrm{pH}$ values among different guava varieties at $p<0.05$ (Table 1 ). Physico-chemical estimations are quite important for consumer acceptability and also found to be suitable for cultivar identification (Padilla-Ramirez et al., 2012). Physical dimensions of fruits also help to calculate the number of fruits to be engaged during possible value additions (Demir \& Hakki Kalyoncu, 2003). Indigenous Pakistani guava cultivars have historically been named by the growers according to their physical dimensions for example Gola and Surahi having round to pear shape fruit, respectively (Mehmood et al, 2014).

Some of the present results are found in close agreement with Mehmood et al. (2014), who studied different genotypes of guava collected from multiple locations of Pakistan. All the tested indigenous guava cultivars contain appreciable amounts of sugars (Table 1); however, Gola found to be the sweetest amongst other counterparts.

Sugars are domineering food constituents that act as an immediate source of energy for the routine body accomplishments. A high sugar level along with total soluble solids often serves as maturity indices in tropical fruits. Table 1 also showed significant correlation between total sugars and total soluble solids. These attributes increase with the passage of time during ripening process, resulting degradation of carbohydrates to soluble sugars (Oms-Oliu et al., 2008). The above cited 
parameters are quite crucial while defining the product for its intended use either as fresh or processed one. In doing so higher titratable acidity and total soluble solids in fruits are required for product development whereas, low acidity and higher soluble solids are desirable for fresh consumption (Padilla-Ramirez et al., 2012).

\subsection{Proximate composition}

Proximate composition of under investigating guava cultivars is presented in Table 2, which indicates insignificant varietal differences in studied parameters. In the study in hand, the moisture contents of fresh guava samples ranged from 82.9 to $84.3 \%$. The cultivars namely Gola, Choti Surahi and Lal Badshah were found statistically $(p<0.05)$ at par regarding their moisture contents whereas Karela cultivar (86.1\%) was statistically different from other guava varieties. Sandhu et al. (2001) also found variation in the moisture content (81.80-87.79\%) of different guava varieties grown in India, which is in close agreement of the current study. Moisture contents significantly affects the overall compositional fraction of biochemical attributes and serve as an important index of freshness as well as storage stability. This reveals that higher moisture level render the fruit to be spoiled earlier and vice versa (Ahmed et al., 2020).
The mean values for Ash contents given in Table 2 manifested that maximum ash contents $(0.68 \%)$ were shown by Sdabahar with non-significant difference was noted between Sufaida and Karela cultivars. In present study, guava cultivars contained appreciable amount of crude fiber with mean values varied from 2.96 to $3.46 \%$. It is evident from Analysis of variance (ANOVA) that no significant varietal difference $(\mathrm{p}<0.05)$ existed in fiber contents. Dietary fiber obtained from fresh fruits is believed to play a significant role in the prevention of chronic and degenerative diseases. Yusof (2003) investigated that carbohydrates are the core component of guava and the composition may differ between the varieties. He also reported that guava carries high moisture, ash and fiber contents but low fat and protein percentages that have also been observed in the present study.

It is believed that nutritional value of the fruit is largely dependent on its proximate composition as also expressed by Ali et al. (2014) and Upadhyay et al. (2019).

\subsection{Mineral components}

Guava fruit is also considered as a rich source of minerals, which plays a key role as cofactor in the human metabolism (Pereira et al., 2014). Table 3 showed that $\mathrm{Na}$ (296.67-332.67 ppm),

Table 1. Physico-chemical analysis of Guava Cultivars.

\begin{tabular}{|c|c|c|c|c|c|c|c|c|c|}
\hline CULTIVARS & $\begin{array}{c}\text { Fruit Size } \\
\mathrm{mm}\end{array}$ & GMD $\mathrm{mm}^{3}$ & Sphericity \% & $\begin{array}{l}\text { Surface Area } \\
\mathrm{mm}^{2}\end{array}$ & $\begin{array}{l}\text { Specific } \\
\text { Gravity }\end{array}$ & TSS ${ }^{\circ}$ Brix & $\mathrm{pH}$ & $\begin{array}{l}\text { TA } \\
\%\end{array}$ & $\begin{array}{c}\text { Total Sugars } \\
\%\end{array}$ \\
\hline GOLA & $80.3 \pm 2.40 b$ & $79.9 \pm 2.15 \mathrm{a}$ & $99.5 \pm 4.01 \mathrm{a}$ & $20077 \pm 25.05 a$ & $1.071 \pm 0.14 \mathrm{a}$ & & $47 \pm 0.60 \mathrm{a}$ & $0.70 \pm 0.12 c$ & $6.74 \pm 1.00 \mathrm{a}$ \\
\hline $\begin{array}{l}\text { CHOTA } \\
\text { GOLA }\end{array}$ & $60.9 \pm 2.88 \mathrm{~d}$ & $59.8 \pm 2.04 \mathrm{f}$ & $98.2 \pm 3.44 c$ & $11226 \pm 13.18 \mathrm{f}$ & $1.055 \pm 0.11 \mathrm{~d}$ & $7.8 \pm 1.15 b$ & $4.30 \pm 0.50 \mathrm{ab}$ & $0.68 \pm 0.52 \mathrm{~cd}$ & $6.52 \pm 0.50 \mathrm{~b}$ \\
\hline SURAHI & $94.6 \pm 1.88 \mathrm{a}$ & $67.0 \pm 3.03 \mathrm{~d}$ & $70.8 \pm 3.27 \mathrm{~h}$ & $14116 \pm 14.37 \mathrm{~d}$ & $1.054 \pm 0.12 \mathrm{~d}$ & $6.3 \pm 1.17 \mathrm{~d}$ & $4.10 \pm 0.70 \mathrm{bc}$ & $0.66 \pm 0.61 \mathrm{de}$ & $6.18 \pm 0.45 c$ \\
\hline $\begin{array}{l}\text { CHOTI } \\
\text { SURAHI }\end{array}$ & $57.8 \pm 1.13 c$ & $50.3 \pm 2.65 \mathrm{~h}$ & $87.0 \pm 2.26 \mathrm{e}$ & $7954 \pm 14.28 \mathrm{~h}$ & $1.062 \pm 0.31 \mathrm{c}$ & $6.8 \pm 0.76 c$ & $4.20 \pm 0.50 \mathrm{bc}$ & $0.76 \pm 0.70 \mathrm{ab}$ & $6.07 \pm 1.00 \mathrm{~cd}$ \\
\hline SUFAIDA & $75.7 \pm 1.28 b$ & $65.2 \pm 3.16 \mathrm{e}$ & $86.1 \pm 3.52 \mathrm{~g}$ & $13339 \pm 22.81 \mathrm{e}$ & $1.071 \pm 0.23 \mathrm{a}$ & $6.4 \pm 1.00 \mathrm{~d}$ & $4.30 \pm 0.40 \mathrm{ab}$ & $0.64 \pm 0.45 \mathrm{e}$ & $5.99 \pm 0.90 \mathrm{~d}$ \\
\hline $\begin{array}{l}\text { LAL } \\
\text { BADSHAH }\end{array}$ & $55.8 \pm 2.28 \mathrm{~cd}$ & $55.4 \pm 3.02 \mathrm{~g}$ & $99.2 \pm 4.28 b$ & $9627 \pm 8.38 \mathrm{~g}$ & $1.067 \pm 0.42 b$ & $5.8 \pm 1.10 \mathrm{e}$ & $4.01 \pm 0.90 \mathrm{~cd}$ & $0.60 \pm 0.50 \mathrm{f}$ & $5.65 \pm 0.50 \mathrm{e}$ \\
\hline SDABAHAR & $69.7 \pm 1.27 b$ & $67.6 \pm 4.05 c$ & $97.1 \pm 2.71 \mathrm{~d}$ & $14371 \pm 21.91 \mathrm{c}$ & $1.061 \pm 0.14 \mathrm{c}$ & $5.6 \pm 1.30 \mathrm{e}$ & $4.00 \pm 1.05 \mathrm{~cd}$ & $0.74 \pm 0.30 \mathrm{~b}$ & $5.22 \pm 0.25 \mathrm{f}$ \\
\hline KARELA & $86.1 \pm 1.69 \mathrm{a}$ & $74.7 \pm 2.73 b$ & $86.7 \pm 3.16 \mathrm{f}$ & $17526 \pm 13.16 b$ & $1.055 \pm 0.55 \mathrm{~d}$ & $5.3 \pm 1.20 \mathrm{f}$ & $3.76 \pm 0.70 \mathrm{~d}$ & $0.78 \pm 0.40 \mathrm{a}$ & $5.01 \pm 0.80 \mathrm{~g}$ \\
\hline
\end{tabular}

Geometric Mean Diameter (GMD), Total Soluble Solids (TSS), Titeratable Acidity (TA), Means with common letters are non-significant at P $<0.05$.

Table 2. Proximate composition of Guava Cultivars.

\begin{tabular}{|c|c|c|c|c|c|c|}
\hline CULTIVARS & Moisture \% & Ash \% & Crude Fiber \% & Crude Fat \% & Crude Protein \% & $\mathrm{TC} \%$ \\
\hline GOLA & $84.3 \pm 1.20 \mathrm{a}$ & $0.65 \pm 0.21 b c$ & $3.40 \pm 0.45 \mathrm{a}$ & $0.90 \pm 0.15 \mathrm{ab}$ & $2.09 \pm 0.35 \mathrm{ab}$ & $8.67 \pm 0.90 \mathrm{~d}$ \\
\hline CHOTA GOLA & $83.1 \pm 1.80 c$ & $0.60 \pm 0.10 \mathrm{e}$ & $3.35 \pm 0.30 \mathrm{a}$ & $0.86 \pm 0.09 b c$ & $2.03 \pm 0.27 \mathrm{bcd}$ & $10.1 \pm 0.12 \mathrm{a}$ \\
\hline SURAHI & $83.2 \pm 1.50 \mathrm{c}$ & $0.63 \pm 0.31 \mathrm{~cd}$ & $3.46 \pm 0.50 \mathrm{a}$ & $0.92 \pm 0.20 \mathrm{a}$ & $2.11 \pm 0.20 \mathrm{a}$ & $9.64 \pm 0.80 \mathrm{ab}$ \\
\hline CHOTI SURAHI & $84.3 \pm 0.90 \mathrm{a}$ & $0.61 \pm 0.20 \mathrm{de}$ & $3.34 \pm 0.30 \mathrm{a}$ & $0.85 \pm 0.15 c$ & $2.04 \pm 0.35 \mathrm{bcd}$ & $8.86 \pm 0.16 \mathrm{~cd}$ \\
\hline SUFAIDA & $82.9 \pm 0.50 c$ & $0.66 \pm 0.25 \mathrm{ab}$ & $3.45 \pm 0.28 \mathrm{a}$ & $0.93 \pm 0.20 \mathrm{a}$ & $2.06 \pm 0.29 \mathrm{abc}$ & $9.94 \pm 0.18 \mathrm{a}$ \\
\hline LAL BADSHAH & $84.2 \pm 1.37 \mathrm{a}$ & $0.59 \pm 0.30 \mathrm{e}$ & $2.96 \pm 0.55 b$ & $0.87 \pm 0.09 b c$ & $2.03 \pm 0.30 \mathrm{~cd}$ & $9.27 \pm 0.38 \mathrm{bc}$ \\
\hline SDABAHAR & $83.1 \pm 2.11 c$ & $0.68 \pm 0.22 \mathrm{a}$ & $3.32 \pm 0.40 \mathrm{a}$ & $0.87 \pm 0.25 \mathrm{bc}$ & $1.99 \pm 0.25 \mathrm{~d}$ & $10.05 \pm 0.15 \mathrm{a}$ \\
\hline KARELA & $83.7 \pm 1.10 \mathrm{~b}$ & $0.67 \pm 0.30 \mathrm{ab}$ & $3.44 \pm 0.50 \mathrm{a}$ & $0.85 \pm 0.16 c$ & $2.02 \pm 0.20 \mathrm{~cd}$ & $9.23 \pm 0.13 b c$ \\
\hline
\end{tabular}

Total Carbohydrates (TC), Means with common letters are not significant at $\mathrm{P}<0.05$. 
$\mathrm{K}$ (3645-4167.7 ppm), Ca (222.1-274.7 ppm), P (87.33-101.0 ppm), $\mathrm{Fe}$ (3.67-7.66 ppm), Mg (201.33-236.33 ppm) and $\mathrm{Zn}$ (9.67-12.66 ppm) were the major minerals estimated in the present study. While taking in account of mineral contents, it was revealed that all the under investigation guava cultivars validated difference in their mineral contents. These variations in mineral contents of tested guava cultivars may be due to the genetic variability, soil chemistry, climate and agricultural practices (Khushk et al., 2009; Chiveu et al., 2019). Guava fruit is known for its higher mineral composition especially $\mathrm{P}, \mathrm{K}, \mathrm{Ca}$, Mg and Zn (Tanwar et al., 2014; Dube \& Singh, 2019). Every mineral has its significant role in human health like; calcium and phosphorus are needed for teeth and bone formation (White \& Broadley, 2009). Whereas, $\mathrm{Na}, \mathrm{K}$ and $\mathrm{Mg}$ are required for neural conduction and muscular contraction (Gharibzahedi \& Jafari, 2017).

Similarly, iron is one of the most cited and extensively studied macromineral with recommended daily allowance of 10-20 mg for humans (WHO, 1996). As a component of hemoglobin as well as an integral part of enzymatic systems, iron plays a significant role in oxygen transport and cellular respiration (Aberoumand \& Deokule, 2009). Results pertaining to mineral composition of guava cultivars (Table 3 ) illustrated that Karela was found to be mineral enriched followed by Sdabahar. Amongst all cultivars, Choti Surahi turned out to be the richest source of magnesium (236.33 ppm) followed by Safaida (235.67 ppm). Substantial amounts of Zn (9.67-12.67) were also present in all the examined guava cultivars which is an integral part of enzymes kinetics and proteins synthesis in humans (Badii et al., 2012). In general, the studied fruit samples had the concentrations of the essential elements above or around the values reported for traditional tropical fruits. The results pertaining to mineral composition of guava were also in close agreement with the findings of Pereira et al. (2014) and Chiveu et al. (2019) who also found guava as a significant source of valuable micronutrients.

\subsection{Nutraceutical analysis}

Nutraceutical potential of guava cultivars was assessed in terms of their ascorbic acid, total phenolic contents (TPC), total flavonoids contents (TFC) and radical scavenging activity (RSA).

\section{Ascorbic acid (vitamin C) contents}

Guava fruit is a richest source of ascorbic acid, which is a potent antioxidant, vital for the treatment of various diseases like common cold, wound healing, anemia, cancer, scurvy, infertility and hemorrhagic disorders. It is worth mentioning that the guava fruit may contain three to four times higher ascorbic acid contents than an average orange fruit (Uddin et al., 2002). Guava fruit may offer approximately (200 to $350 \mathrm{mg} / 100 \mathrm{~g}$ ) of ascorbic acid contents depending upon their varietal type (Kaur et al., 2009; Rana et al., 2015).

Tukey test showed that the guava cultivars were significantly different at $p<0.05$ in terms of their ascorbic acid contents. Gola was found to be the richest $(289.43 \mathrm{mg} / 100 \mathrm{~g})$ in terms of ascorbic contents followed by Sufaida (250.82). According to Ali, Ahmed \& Babikir (2014), the variation in ascorbic acid ( 190.96 to $250.77 \mathrm{mg} / 100 \mathrm{~g}$ ) were estimated in different guava cultivars which are also in line with the current investigation. According to Mehmood et al. (2014) ascorbic acid contents in Pakistani guava genotypes ranged between $49.2-233.3 \mathrm{mg} / 100 \mathrm{~g}$. The concentration of ascorbic acid varies with maturity stage and environmental conditions. However, slow respiration rate also reduces ascorbic acid contents due to its subsequent conversion into dehydroascorbic acid through the activity of ascorbic acid oxidase enzymes (Sahoo et al., 2015; Murmu \& Mishra, 2018). Rajkumar et al. (2016) also reported seasonal based variation in ascorbic acid contents, who observed increased ascorbic acid contents in winter fruits as compare to those harvested during summer season.

\section{Estimation of total phenolic contents, flavonoids contents and RSA \%}

Bioactive compounds in terms of total phenolic contents and total flavonoid contents were estimated in guava cultivars under study. Fruits are supposed to contain diversified bioactive compounds, which demonstrate biological activity in terms of antioxidant, antimicrobial and anticancer properties. These chemical classes have considerable disease preventing and health promoting effects on human body (Han et al., 2018).

Total phenolic contents (TPC) ranged between 94.06 and $190.64 \mathrm{mg} \mathrm{GAE} / 100 \mathrm{~g}$ (Table 4$)$. Data related to TPC showed highly significant difference $(p<0.05)$ existed amongst the

Table 3. Minerals composition of Guava Cultivars.

\begin{tabular}{|c|c|c|c|c|c|c|c|}
\hline CULTIVARS & $\mathrm{Na}(\mathrm{ppm})$ & $\mathrm{K}(\mathrm{ppm})$ & $\mathrm{Ca}(\mathrm{ppm})$ & $\mathrm{P}(\mathrm{ppm})$ & $\mathrm{Fe}(\mathrm{ppm})$ & $\mathrm{Mg}(\mathrm{ppm})$ & $\mathrm{Zn}(\mathrm{ppm})$ \\
\hline CHOTA GOLA & $312.33 \pm 3.21 \mathrm{~d}$ & $3740.0 \pm 20.5 \mathrm{e}$ & $268.3 \pm 2.52 \mathrm{ab}$ & $90.33 \pm 2.58 b c$ & $3.67 \pm 0.19 \mathrm{~d}$ & $214.33 \pm 4.04 \mathrm{bc}$ & $10.33 \pm 0.51 b c$ \\
\hline CHOTI SURAHI & $330.33 \pm 4.12 \mathrm{ab}$ & $3871.3 \pm 36.1 \mathrm{~cd}$ & $265.3 \pm 4.51 \mathrm{ab}$ & $87.33 \pm 5.08 c$ & $3.66 \pm 0.36 \mathrm{~d}$ & $236.33 \pm 3.06 \mathrm{a}$ & $10.33 \pm 0.24 b c$ \\
\hline SUFAIDA & $296.67 \pm 2.13 \mathrm{e}$ & $3645.0 \pm 31.0 \mathrm{f}$ & $274.7 \pm 3.06 \mathrm{a}$ & $90.33 \pm 4.58 \mathrm{bc}$ & $4.33 \pm 0.24 \mathrm{~cd}$ & $235.67 \pm 3.17 \mathrm{a}$ & $10.65 \pm 0.64 b c$ \\
\hline SDABAHAR & $312.33 \pm 2.52 \mathrm{~d}$ & $4094.3 \pm 55.0 \mathrm{~b}$ & $222.1 \pm 1.15 \mathrm{e}$ & $91.00 \pm 3.10 \mathrm{bc}$ & $6.67 \pm 0.45 \mathrm{ab}$ & $212.33 \pm 1.53 c$ & $9.67 \pm 0.63 c$ \\
\hline KARELA & $332.67 \pm 3.51 \mathrm{a}$ & $4167.7 \pm 39.5 \mathrm{a}$ & $244.3 \pm 4.04 c$ & $98.00 \pm 2.29 \mathrm{ab}$ & $7.66 \pm 0.28 \mathrm{a}$ & $216.00 \pm 4.18 \mathrm{bc}$ & $10.66 \pm 0.74 b c$ \\
\hline
\end{tabular}

Sodium (Na), Potassium (K), Calcium (Ca), Phosphorous (P), Iron (Fe), Magnesium (Mg), Zinc (Zn); Means with common letters are non-significant at $\mathrm{P}<0.05$. 
studied guava cultivars. Likewise, ascorbic acid contents, the highest TPC were estimated in Gola variety $(190.64 \mathrm{mg}$ GAE/100 g) and lowest in Sdabahar (94.06 mg GAE/100 g). The total flavonoid contents (TFC) were assessed on the basis of $\mathrm{mg} / 100 \mathrm{~g}$ of quercetin equivalents which were varied from 81.30 to $154.19 \mathrm{mg} \mathrm{QE} / 100 \mathrm{~g}$ among the tested cultivars. The significant variations among all tested varieties were also in line with the earlier studies of Alothman et al. (2009) who found TPC ranges from 109 to $191 \mathrm{mg} \mathrm{GAE} / 100 \mathrm{~g}$ of fresh weight while TFC from 13.9 to $40.9 \mathrm{mg}$ CEQ/100 g. Similarly, radical scavenging activity (DPPH inhibition percentage) varies from 36.8 to $71 \%$ in different guava cultivars. Almost similar trend was observed in the results pertaining to antioxidant activity in terms of their DPPH radical scavenging activity (RSA \%) as presented in Table 4.

Nutraceutical potential due to the presence of different bioactive compounds in fruits is much accepted profile that determines their quality in terms of their intended use (Ali et al., 2011). The fruits are purposely being selected in view of their specific health benefits beyond basic nutrition. Present study showed remarkable nutraceutical potential in the tested Guava cultivars (Table 4). In addition, the same has also been confirmed through significant correlation observed between estimated bioactive compounds and radical scavenging activity. This correlation has also been reported by different other researchers like; dos Santos et al (2017), Abbasi et al (2019) and Rehman et al. (2019). Based upon our investigations, we can say that the guava cultivars are effective free radical scavengers. Flores et al. (2015) also suggested that guava cultivars may be exploited as a potent source of natural antioxidants for food, pharmaceutical, medical and commercial uses.

\subsection{Sensory evaluation}

Table 5 showed data related to the sensory evaluation of tested guava cultivars. Amongst studied cultivars, Gola received the highest sensorial scores (8.8) on a 9-point hedonic scale $(p<0.05)$. In terms of their skin color, selected guava cultivars were statistically at par (Table 5). Guava fruit carries three-maturity stages viz un-ripe, semi ripe and full ripe which would be distinguished by the fruit color (Gull et al., 2012). Color is the most important sensory attribute perceived by the consumer and grower being a critical component of fruit maturity index (Bashir \& Abu-Goukh, 2003). Likewise, there was no significant difference $(p<0.05)$ among the tested guava cultivars regarding the texture of the fruit. Texture is another important quality attribute of fruits. Sensorial texture of fresh fruits is a complex manifestation of perceptions by the senses of touch, vision, hearing and kinaesthesia (Waldron et al., 2003). Texture of fruits and vegetable products is primarily associated to the structural integrity and firmness that is mainly established by the network of cellulose, hemicellulose and pectin. This interwoven network plays a significant role during postharvest processing and storage stability of fruits (Cruz, 2011).

Aroma is a distinct feature of guava fruit due to the presence of different volatile and non-volatile compounds such as (E)-2-hexenal, Z-3-hexenal, Z-3-hexenyl acetate, E-3-hexenyl

Table 4. Nutraceutical analysis of Guava Cultivars.

\begin{tabular}{lcccc}
\hline \multicolumn{1}{c}{ CULTIVARS } & ASCORBIC ACID $(\mathrm{mg} / 100 \mathrm{~g})$ & TPC $(\mathrm{mg}$ GAE $/ 100 \mathrm{~g})$ & TFC $(\mathrm{mg}$ QE/ $100 \mathrm{~g})$ & RSA $\%$ \\
\hline GOLA & $289.43 \pm 0.97 \mathrm{a}$ & $190.64 \pm 0.11 \mathrm{a}$ & $154.19 \pm 0.21 \mathrm{a}$ & $78.15 \pm 0.16 \mathrm{a}$ \\
CHOTA GOLA & $234.32 \pm 0.29 \mathrm{e}$ & $104.94 \pm 0.22 \mathrm{e}$ & $97.37 \pm 0.15 \mathrm{~d}$ & $38.07 \pm 0.43 \mathrm{e}$ \\
SURAHI & $244.43 \pm 0.75 \mathrm{~d}$ & $115.97 \pm 0.18 \mathrm{~d}$ & $100.56 \pm 0.37 \mathrm{c}$ & $42.46 \pm 0.41 \mathrm{~d}$ \\
CHOTI SURAHI & $246.20 \pm 0.10 \mathrm{c}$ & $118.60 \pm 0.21 \mathrm{c}$ & $101.31 \pm 0.38 \mathrm{c}$ & $44.57 \pm 0.41 \mathrm{c}$ \\
SUFAIDA & $250.82 \pm 0.40 \mathrm{~b}$ & $121.49 \pm 0.46 \mathrm{~b}$ & $103.45 \pm 0.14 \mathrm{~b}$ & $47.77 \pm 0.67 \mathrm{~b}$ \\
LAL BADSHAH & $227.95 \pm 0.36 \mathrm{~g}$ & $100.19 \pm 0.31 \mathrm{~g}$ & $94.33 \pm 0.96 \mathrm{e}$ & $31.14 \pm 0.76 \mathrm{~g}$ \\
SDABAHAR & $222.26 \pm 0.25 \mathrm{~h}$ & $94.06 \pm 0.26 \mathrm{~h}$ & $81.30 \pm 0.31 \mathrm{f}$ & $27.70 \pm 0.40 \mathrm{~h}$ \\
KARELA & $229.80 \pm 0.26 \mathrm{f}$ & $102.19 \pm 0.47 \mathrm{f}$ & $94.57 \pm 0.32 \mathrm{e}$ & $34.37 \pm 0.22 \mathrm{f}$ \\
\hline
\end{tabular}

Total Phenolic Compounds (TPC), Total Flavonoid Compounds (TFC), Radical Scavenging Activity (RSA); Means with common letters are non-significant at P < 0.05.

Table 5. Sensory evaluation of guava cultivars.

\begin{tabular}{lcllc}
\hline \multicolumn{1}{c}{ CULTIVARS } & Color & Aroma & Taste & Texture \\
\hline GOLA & $8.0 \mathrm{a}$ & $8.0 \mathrm{a}$ & $8.8 \mathrm{a}$ & $8.0 \mathrm{a}$ \\
CHOTA GOLA & $6.4 \mathrm{ab}$ & $6.4 \mathrm{abcd}$ & $6.4 \mathrm{bc}$ & $6.4 \mathrm{ab}$ \\
SURAHI & $6.6 \mathrm{ab}$ & $6.6 \mathrm{abc}$ & $6.6 \mathrm{abc}$ & $7.0 \mathrm{ab}$ \\
CHOTI SURAHI & $6.6 \mathrm{ab}$ & $6.8 \mathrm{ab}$ & $7.2 \mathrm{ab}$ & $6.6 \mathrm{ab}$ \\
SUFAIDA & $6.4 \mathrm{ab}$ & $6.2 \mathrm{abcd}$ & $6.4 \mathrm{bc}$ & $5.0 \mathrm{ab}$ \\
LAL BADSHAH & $5.2 \mathrm{bc}$ & $5.2 \mathrm{bcd}$ & $5.2 \mathrm{bcd}$ & $5.2 \mathrm{~b}$ \\
SDABAHAR & $3.8 \mathrm{c}$ & $4.6 \mathrm{~d}$ & $4.6 \mathrm{~cd}$ & $5.2 \mathrm{~b}$ \\
KARELA & $5.0 \mathrm{bc}$ & $4.8 \mathrm{~cd}$ & $4.0 \mathrm{~d}$ & \\
\hline
\end{tabular}


Table 6. Correlation among Physico-chemical attributes.

\begin{tabular}{|c|c|c|c|c|c|c|c|c|}
\hline Variables & Fruit Size & GMD & Sphericity & Surface Area & $\begin{array}{l}\text { Specific } \\
\text { Gravity }\end{array}$ & TSS & $\mathrm{pH}$ & $\begin{array}{c}\text { Titratable } \\
\text { Acidity }\end{array}$ \\
\hline GMD & 0.5842 & & & & & & & \\
\hline Surface Area & 0.5633 & 0.9974 & 0.0253 & & & & & \\
\hline Specific Gravity & -0.2536 & 0.0794 & 0.4233 & 0.1044 & & & & \\
\hline $\mathrm{pH}$ & -0.3355 & 0.0297 & 0.2027 & 0.0487 & 0.4904 & 0.8578 & & \\
\hline Titratable Acidity & 0.1774 & 0.2295 & -0.0269 & 0.2542 & -0.3626 & -0.1077 & -0.2681 & \\
\hline Total Sugars & -0.2990 & -0.0160 & 0.0569 & 0.0056 & 0.2417 & 0.9398 & 0.8443 & -0.3202 \\
\hline
\end{tabular}

Table 7. Correlation among nutraceutical attributes.

\begin{tabular}{cccc}
\hline Variables & Ascorbic Acid & TPC & TFC \\
\hline TPC & 0.9855 & & \\
TFC & 0.9705 & 0.9896 & \\
RSA\% & 0.9970 & 0.9897 & 0.9792 \\
\hline
\end{tabular}

acetate, sesquiterpenes caryophyllene, a-humulene and b-bisabollene (Soares et al., 2007). Regarding aroma, the under trial guava cultivars were partially different with each other.

Taste is mostly assessed in terms of sweetness, saltiness, bitterness and sourness (Iatridi et al., 2019). Fruits are usually consumed as dessert and liked due to their sweetness scores. Data related to taste scores showed that Gola was found to be the most acceptable cultivar while the panelists considered Karela variety the least acceptable. This might be due to high sugars and total soluble solids estimated in Gola cultivar as presented in Table 1. The findings of current evaluation were also in conformity to Usman et al. (2012) who reported that Gola and Surahi are the most preferred commercial guava cultivars due to their sweet taste and high total soluble solids.

\subsection{Multivariate analysis}

Use of Multivariate analysis in the discipline of food science is novel technique applied to data set of quantitative and qualitative traits (Qannari, 2017). In present study, selected eight indigenous guava cultivars were characterized on the basis of sum of 31 different traits. The data pertaining to Pearson's correlation indicated the highly significant correlation (Table 6) between GMD and surface area $\left(\mathrm{R}^{2}=0.9974 p<0.05\right)$ that is why the average increase in GMD, the surface area will also be increased (Ali et al., 2011; Abbasi et al., 2019). Among chemical parameters significant correlation was found between TSS and total sugars $\left(\mathrm{R}^{2}=0.9398 p<0.05\right), \mathrm{pH}$ and total sugars $\left(\mathrm{R}^{2}=0.8443 p<0.05\right)$, TSS and $\mathrm{pH}\left(\mathrm{R}^{2}=0.8578 p<0.05\right)$. A major correlation was established among the bioactive antioxidant components and radical scavenging potential of guava fruit of all selected cultivars (Table 7). The correlation between antioxidant activity and total phenolic compounds has been extensively studied in different fruit and vegetables (Abbasi et al., 2019). The ascorbic acid contents being a predominant antioxidant found in guava fruit were significantly correlated with other functional parameters like RSA $\left(\mathrm{R}^{2}=0.9970 p<0.05\right)$, TPC $\left(\mathrm{R}^{2}=0.9855 p<0.05\right)$ and TFC $\left(\mathrm{R}^{2}=0.9705 p<0.05\right)$.

\section{Principal Component Analysis (PCA)}

PCA is statistical cum mathematical tool to identify variation present in the dataset usually to characterize the samples by using a small number of factors. In this study, Principal Component Analysis put analyzed attributes into seven components that explained total variation (Table 8). The first component, which accounted for $44.28 \%$ of the total variation, predominantly incorporated crude protein, crude fat, calcium, TSS, total sugars, nutraceutical and sensory characters. The second component, which explained $21.71 \%$ of the total variation, included attributes like crude fiber, ash, potassium, phosphorus, iron, zinc, fruit size, GMD and surface area. The third component, elucidating $12.1 \%$ of the total variation, was the function of sphericity, total carbohydrates and moisture.

The fourth component, explaining for $9.42 \%$ of the total variation while fifth component of PCA revealed $6.42 \%$ of the total variation. The sixth component was mainly the function of magnesium only and showed $4.69 \%$ of total variation; whereas the last component explained negligibly low variation (1.39\%). Figure 1 depicts a two dimensional PCA plot primarily based on the first two principal components explaining $65.98 \%$ of the total variation. The plot clustered the tested cultivars according to their quantitative and qualitative traits. For example, the cultivars Gola and Surahi having higher values in most of the parameters were placed in the upper right plane while cultivars namely Sufaida, Choti Surahi and Chota Gola were set in the lower right plane having moderate values in physical and sensory attributes. Karela cultivar was placed in the upper left plane and mainly the function of higher iron contents while Lal Badshah and Sdabahar having lowest estimations in most of the traits were placed far in left plane. The results demonstrate that the nutraceutical and sensory characters are highly correlated therefore, led to the highest loading factors in PCA. It also reveals that Gola cultivar performs exceptionally better than its counterparts thus occupied distinguish place at upper right corner in 2D plot. dos Santos et al. (2017) used PCA to quantify phenolic compounds in 96 guava fruit pulps (Psidium guajava L.) and found $60 \%$ of data variability with two principal components. 
Table 8. First 7 components from the PCA analysis of 31 traits of eight indigenous guava cultivars.

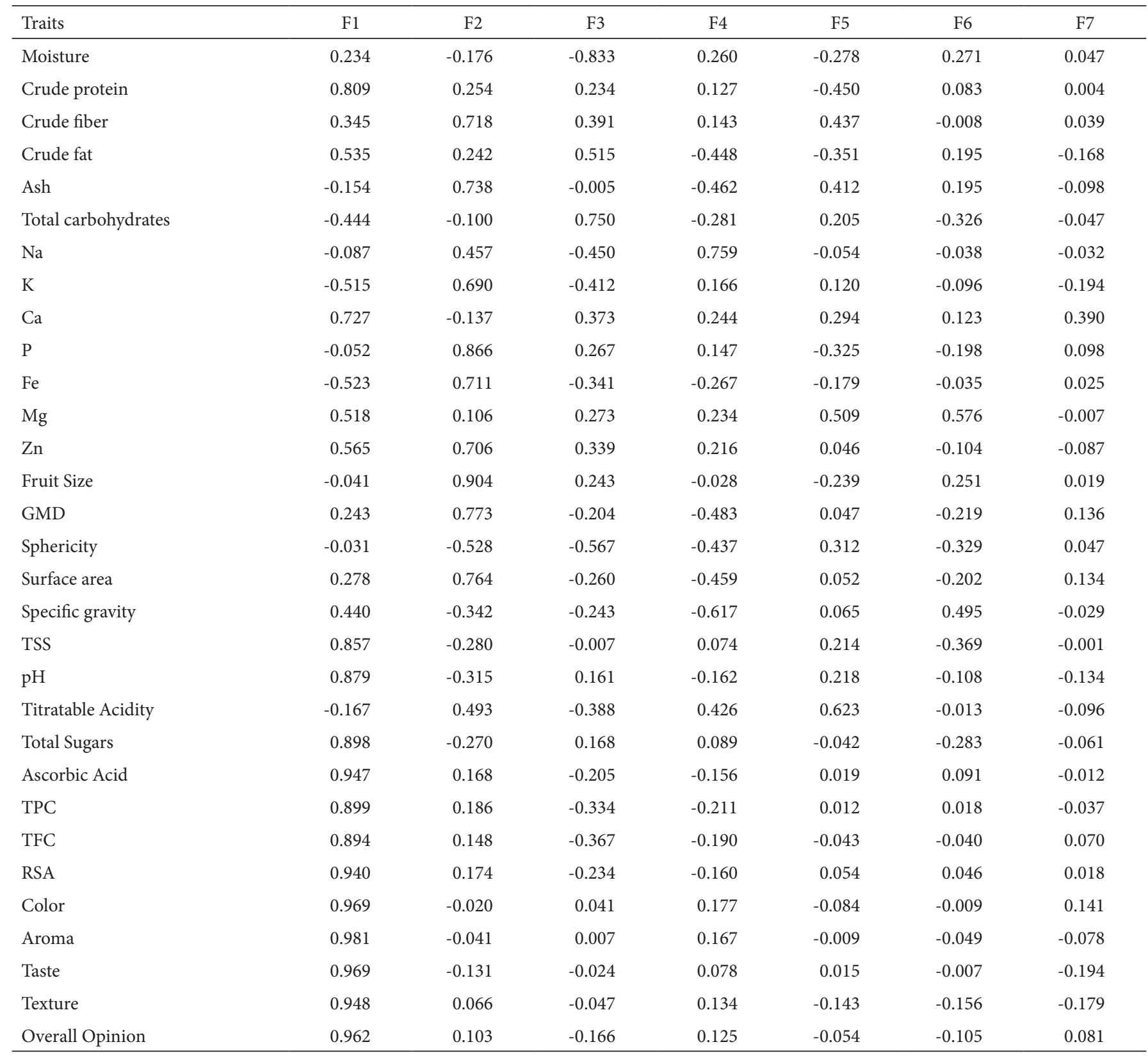

The results of our investigation are in line with the findings of Flores et al. (2015) who also performed principal component analysis while studying chemical composition and antioxidant activity of seven guava cultivars.

\section{Hierarchical cluster analysis (HCA)}

HCA is a clustering method which explore the dissimilarities among samples presented in groups and among groups illustrating a hierarchy (Granato et al., 2018). In present study, hierarchical cluster analysis (HCA) was performed by using Ward's method for the agglomeration and Euclidean distance was used to explore dissimilarities in eight indigenous guava cultivars.

In doing so, the dendogram (Figure 2) revealed three distinct classes. The first two classes were separated with a dissimilarity result of $74 \times 10^{6}$. Gola and Karela cultivar form the first separated class while in second class three cultivars namely Chota Gola, Choti Surahi and Lal Badshah were placed. The third group of class included Surahi, Sufaida and Sdabahar and was separated with a dissimilarity result of $42 \times 10^{6}$. From HCA, one can observe high level of dissimilarity amongst Surahi, Sufaida and Sdabahar while on the other hand Gola and Karela were remarkably different in terms of relatively low similarity. This may leads to inconsistency in genetic material of guava cultivars. The illustrated results are also in conformity to the findings of Mehmood et al. (2014) who performed HCA to check genetic variability among guava accessions grown in different agro ecological zones of Pakistan. 
Biplot (axes F1 and F2: $65.98 \%$ )

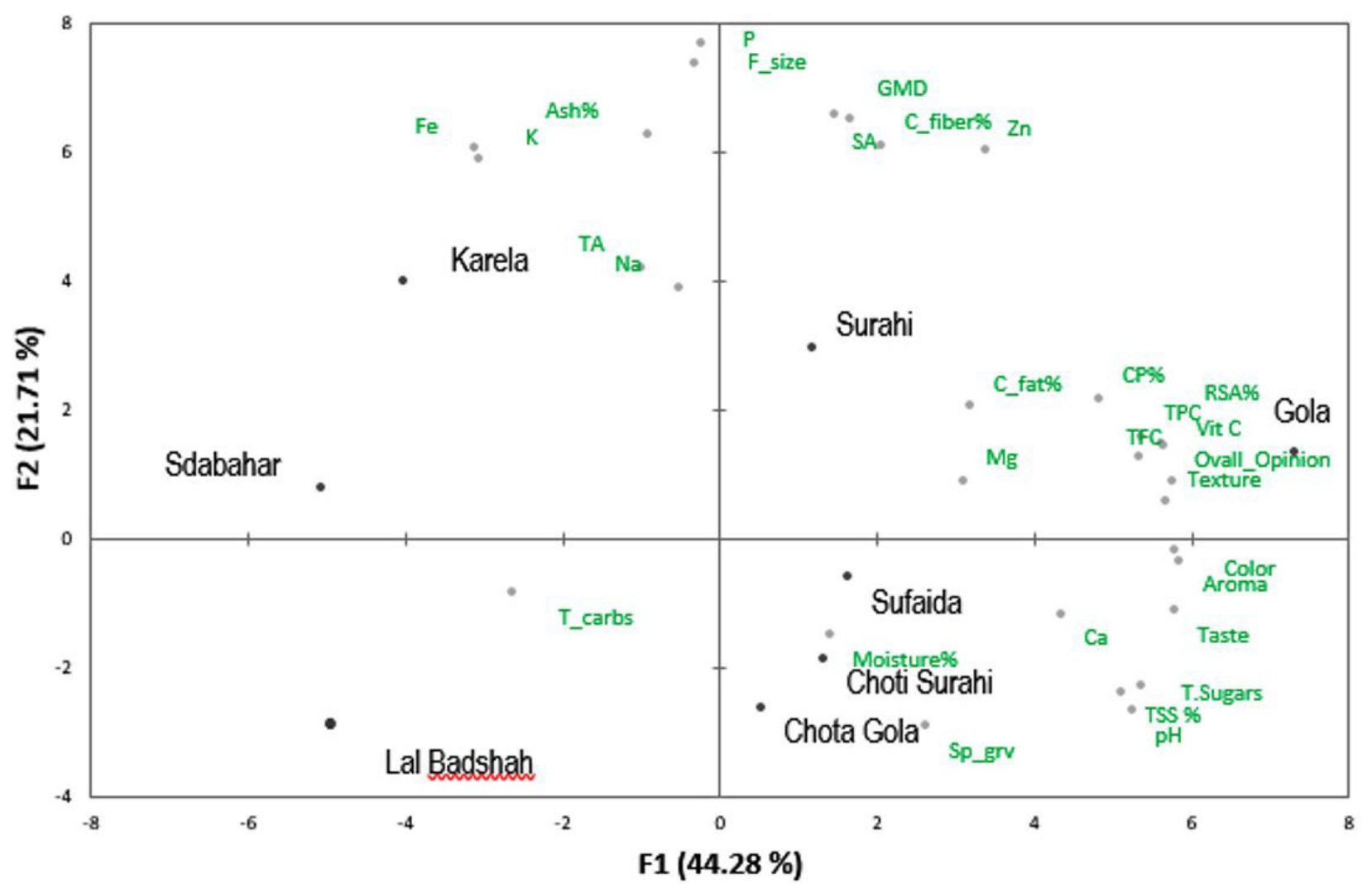

Figure 1. Two-dimensional PCA (2-D) plot based on the first two components (F1 \& F2) for 31 different traits of indigenous guava cultivars. Fe [Iron], K [Potassium], TA [Titratable Acidity], Na [Sodium], P [Phosphorous], F_size [Fruit size], GMD [Geometric mean diameter], C_fiber [Crude fiber], Zn [Zinc], SA [Surface area], C_fat [Crude fat], CP [Crude protein], RSA [Radical scavenging activity], TPC [Total phenolic contents], TFC [Total flavonoid contents], Mg [Magnesium], T_carbs [Total carbohydrates], Ca [Calcium], Sp_grv [Specific gravity], T.Sugars [Total sugars], TSS [Total soluble solids].

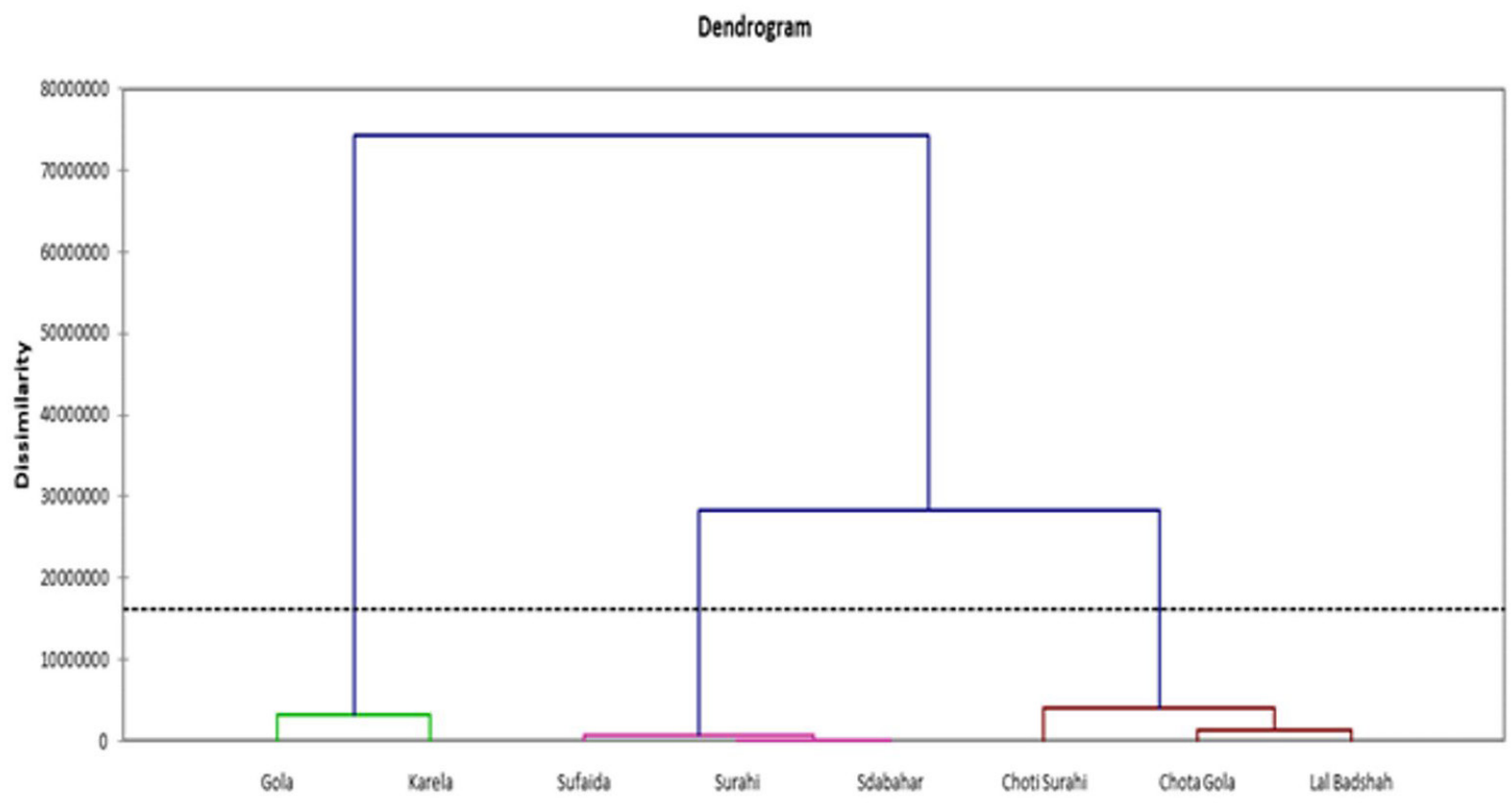

Figure 2. Dendrogram for guava cultivars based on 31 different parameters. 


\section{Conclusion}

It was concluded from the present study that the indigenous guava cultivars are remarkably rich in nutritional and antioxidant composition i.e. ascorbic acid, phenolic compounds, flavonoids and antioxidant activity. Considerable amounts of different minerals like $\mathrm{K}, \mathrm{P}, \mathrm{Mg}, \mathrm{Ca}, \mathrm{Na}, \mathrm{Zn}$ and Fe were also present in guava cultivars. It is expected that the research outcome will provide baseline for the farmers, researchers, scientists, technologists, exporters and other stake holders to realize the ultimate potential of indigenous guava cultivars and their intended use. This study also provides basic technological information about guava varieties to be helpful in the development of postharvest management system and industrialized value addition of this vital fruit.

\section{References}

Abbasi, K. S., Masud, T., Qayyum, A., Khan, S. U., Ahmad, A., Mehmood, A., Farid, A., \& Jenks, M. A. (2016). Transition in quality attributes of potato under different packaging systems during storage. Journal of Applied Botany and Food Quality, 89(1), 142-149.

Abbasi, K. S., Qayyum, A., Mehmood, A., Mahmood, T., Khan, S. U., Liaquat, M., Sohail, A., \& Ahmad, A. (2019). Analysis of selective potato varieties and their functional assessment. Food Science and Technology, 39(2), 308-314. https://doi.org/10.1590/fst.26217.

Aberoumand, A., \& Deokule, S. S. (2009). Determination of elements profile of some wild edible plants. Food Analytical Methods, 2(2), 116-119. http://dx.doi.org/10.1007/s12161-008-9038-z.

Ahmadi, H., Fathollahzadeh, H., \& Mobli, H. (2008). Some physical and mechanical properties of apricot fruits, pits and kernels $(\mathrm{CV}$ Tabarzeh). American-Eurasian Journal of Agricultural \& Environmental Sciences, 3(5), 703-707.

Ahmed, A., Ali, S. W., Imran, A., Afzaal, M., Arshad, M. S., Nadeem, M., Mubeen, Z., \& Ikram, A. (2020). Formulation of date pit oil-based edible wax coating for extending the storage stability of guava fruit. Journal of Food Processing and Preservation, 44(2), 1-10. http:// dx.doi.org/10.1111/jfpp.14336.

Ali, D. O., Ahmed, A. R., \& Babikir, E. B. (2014). Physicochemical and nutritional value of red and white guava cultivars grown in Sudan. Journal of Agriculture and Applied Sciences, 2(2), 27-30.

Ali, S., Masud, T., \& Abbasi, K. S. (2011). Physico-chemical characteristics of apricot (Prunus armeniaca L.) grown in Northern Areas of Pakistan. Scientia Horticulturae, 130(2), 386-392. http://dx.doi. org/10.1016/j.scienta.2011.05.040.

Alothman, M., Bhat, R., \& Karim, A. A. (2009). Antioxidant capacity and phenolic content of selected tropical fruits from Malaysia, extracted with different solvents. Food Chemistry, 115(3), 785-788. http://dx.doi.org/10.1016/j.foodchem.2008.12.005.

Amerine, M. A., Pangborn, R. M., \& Roessler, E. B. (2013). Principles of sensory evaluation of food. New York: Academic Press.

Association of Official Analytical Chemists - AOAC. (2005). Official methods of analysis (18 $18^{\text {th }}$ ed.). Arlington: AOAC.

Badii, A., Nekouei, N., Fazilati, M., Shahedi, M., \& Badiei, S. (2012). Effect of consuming zinc-fortified bread on serum zinc and iron status of zinc-deficient women: a double blind, randomized clinical trial. International Journal of Preventive Medicine, 3(Suppl1), S124-S130. PMid:22826754.
Baryeh, E. A. (2001). Physical properties of bambara groundnuts. Journal of Food Engineering, 47(4), 321-326. http://dx.doi.org/10.1016/ S0260-8774(00)00136-9.

Bashir, H. A., \& Abu-Goukh, A. B. A. (2003). Compositional changes during guava fruit ripening. Food Chemistry, 80(4), 557-563. http:// dx.doi.org/10.1016/S0308-8146(02)00345-X.

Chiveu, J., Naumann, M., Kehlenbeck, K., \& Pawelzik, E. (2019). Variation in fruit chemical and mineral composition of Kenyan guava (Psidium guajava L.): Inferences from climatic conditions, and fruit morphological traits. Journal of Applied Botany and Food Quality, 92, 151-159.

Cruz, R. (2011). Practical food and research. New York: Nova Science Publishers.

Demir, F., \& Hakki Kalyoncu, İ. (2003). Some nutritional, pomological and physical properties of cornelian cherry (Cornus mas L.). Journal of Food Engineering, 60(3), 335-341. http://dx.doi.org/10.1016/ S0260-8774(03)00056-6.

Dube, A., \& Singh, P. (2019). Compositional evaluation of guava (Psidium guajava L.) cv. L-49 during fruit growth and development. Journal of Pharmacognosy \& Phytochemistry, 8(5), 68-71.

Flores, G., Wu, S. B., Negrin, A., \& Kennelly, E. J. (2015). Chemical composition and antioxidant activity of seven cultivars of guava (Psidium guajava) fruits. Food Chemistry, 170, 327-335. http://dx.doi. org/10.1016/j.foodchem.2014.08.076. PMid:25306353.

Food and Agricultural Organization of the United Nations - FAO. (2017). Production of mangoes, mangos teen and guava for the year 2014. Rome: FAO.

Gharibzahedi, S. M. T., \& Jafari, S. M. (2017). The importance of minerals in human nutrition: bioavailability, food fortification, processing effects and nanoencapsulation. Trends in Food Science \& Technology, 62, 119-132. http://dx.doi.org/10.1016/j.tifs.2017.02.017.

Government of Pakistan. Ministry of National Food Science and Research. (2018). Agricultural Statistics of Pakistan - Economic Wing, Islamabad. Pakistan: Ministry of National Food Science and Research.

Granato, D., Santos, J. S., Escher, G. B., Ferreira, B. L., \& Maggio, R. M. (2018). Use of principal component analysis (PCA) and hierarchical cluster analysis (HCA) for multivariate association between bioactive compounds and functional properties in foods: a critical perspective. Trends in Food Science \& Technology, 72, 83-90. http:// dx.doi.org/10.1016/j.tifs.2017.12.006.

Gull, J., Sultana, B., Anwar, F., Naseer, R., Ashraf, M., \& Ashrafuzzaman, M. (2012). Variation in antioxidant attributes at three ripening stages of guava (Psidium guajava L.) fruit from different geographical regions of Pakistan. Molecules (Basel, Switzerland), 17(3), 3165-3180. http://dx.doi.org/10.3390/molecules17033165. PMid:22418924.

Gupta, M., Wali, A., Gupta, S., \& Annepu, S. K. (2018). Nutraceutical potential of Guava. In J.-M. Mérillon \& K. G. Ramawat (Eds.), Bioactive molecules in food (pp. 1-27). USA: Springer International Publishing.

Han, H., Yılmaz, H., \& Gülçin, İ. (2018). Antioxidant activity of flaxseed (Linum usitatissimum L.) shell and analysis of Its polyphenol contents by LC-MS/MS. Records of Natural Products, 12(4), 397-402. http:// dx.doi.org/10.25135/rnp.46.17.09.155.

Hassan, I., Khurshid, W., \& Iqbal, K. (2012). Factors responsible for decline in guava (Psidium guajava) yield. Journal of Agricultural Research, 50(1), 129-134.

Hassimotto, N. M. A., Genovese, M. I., \& Lajolo, F. M. (2005). Antioxidant activity of dietary fruits, vegetables, and commercial frozen fruit 
pulps. Journal of Agricultural and Food Chemistry, 53(8), 2928-2935. http://dx.doi.org/10.1021/jf047894h. PMid:15826041.

Ho, R., Violette, A., Cressend, D., Raharivelomanana, P., Carrupt, P. A., \& Hostettmann, K. (2012). Antioxidant potential and radical-scavenging effects of flavonoids from the leaves of Psidium cattleianum grown in French Polynesia. Natural Product Research, 26(3), 274-277. http://dx.doi.org/10.1080/14786419.2011.585610 . PMid:22077157.

Iatridi, V., Hayes, J. E., \& Yeomans, M. R. (2019). Quantifying sweet taste liker phenotypes: Time for some consistency in the classification criteria. Nutrients, 11(1), 129. http://dx.doi.org/10.3390/nu11010129. PMid:30634558.

Joseph, B., \& Priya, M. (2011). Review on nutritional, medicinal and pharmacological properties of guava (Psidium guajava Linn.). International Journal of Pharma and Bio Sciences, 2(1), 53-69.

Kadam, D. M., Kaushik, P., \& Kumar, R. (2012). Evaluation of guava products quality. International Journal of Food Science and Nutrition Engineering, 2(1), 7-11. http://dx.doi.org/10.5923/j.food.20120201.02.

Kaur, S., Sarkar, B. C., Sharma, H. K., \& Singh, C. (2009). Optimization of enzymatic hydrolysis pretreatment conditions for enhanced juice recovery from guava fruit using response surface methodology. Food and Bioprocess Technology, 2(1), 96-100. http://dx.doi.org/10.1007/ s11947-008-0119-1.

Khushk, A. M., Memon, A., \& Lashari, M. I. (2009). Factors affecting guava production in Pakistan. Journal of Agricultural Research, 47(2), 201-210.

Kyriacou, M. C., Ioannidou, S., Nikoloudakis, N., Seraphides, N., Papayiannis, L. C., \& Kyratzis, A. C. (2020). Physicochemical characterization and trait stability in a genetically diverse ex situ collection of pomegranate (Punica granatum L.) germplasm from Cyprus. Scientia Horticulturae, 263, 109116. http://dx.doi. org/10.1016/j.scienta.2019.109116.

Mehmood, A., Jaskani, M. J., Khan, I. A., Ahmad, S., Ahmad, R., Luo, S., \& Ahmad, N. M. (2014). Genetic diversity of Pakistani guava (Psidium guajava L.) germplasm and its implications for conservation and breeding. Scientia Horticulturae, 172, 221-232. http://dx.doi. org/10.1016/j.scienta.2014.04.005.

Murmu, S. B., \& Mishra, H. N. (2018). The effect of edible coating based on Arabic gum, sodium caseinate and essential oil of cinnamon and lemon grass on guava. Food Chemistry, 245, 820-828. http://dx.doi. org/10.1016/j.foodchem.2017.11.104. PMid:29287447.

Oms-Oliu, G., Soliva-Fortuny, R., \& Martín-Belloso, O. (2008). Edible coatings with antibrowning agents to maintain sensory quality and antioxidant properties of fresh-cut pears. Postharvest Biology and Technology, 50(1), 87-94. http://dx.doi.org/10.1016/j. postharvbio.2008.03.005.

Padilla-Ramirez, J. S., Gonzalez-Gaona, E., \& Ambriz-Aguilar, J. (2012). Internationalmarket of fresh and processed guava: challenges and perspectives for the Mex-ican case. Acta Horticulturae, (959), 15-22. http://dx.doi.org/10.17660/ActaHortic.2012.959.1.

Pereira, M. C., Boschetti, W., Rampazzo, R., Celso, P. G., Hertz, P. F., Rios, A. D. O., Vizzotto, M., \& Flores, S. H. (2014). Mineral characterization of native fruits from the southern region of Brazil. Food Science and Technology (Campinas), 34(2), 258-266. http:// dx.doi.org/10.1590/fst.2014.0049.

Qannari, E. M. (2017). Sensometrics approaches in sensory and consumer research. Current Opinion in Food Science, 15, 8-13. http://dx.doi. org/10.1016/j.cofs.2017.04.001.

Rajkumar, G. K., Mann, A., Lata, C., Singh, A., \& Kumar, A. (2016). Biochemical changes in guava (Psidium guajava) cv. Allahabad
Safeda fruits as a function of maturity stages. Indian Journal of Agricultural Sciences, 86(12), 1595-1600.

Rana, S., Siddiqui, S., \& Goyal, A. (2015). Extension of the shelf life of guava by individual packaging with cling and shrink films. Journal of Food Science and Technology, 52(12), 8148-8155. http://dx.doi. org/10.1007/s13197-015-1881-5. PMid:26604388.

Rehman, S. U., Abbasi, K. S., Qayyum, A., Jahangir, M., Sohail, A., Nisa, S., Tareen, M. N., Tareen, M. J., \& Sopade, P. (2019). Comparative analysis of citrus fruits for nutraceutical properties. Food Science \& Technology, 40(Suppl. 1), 153-157. https://doi. org/10.1590/fst.07519.

Rodríguez, N. N., Valdés, J., Rodríguez, J. A., Velásquez, J. B., Rivero, D., Martínez, F., Gonzalez, G., Sourd, D. G., Gonzalez, L., \& Cañizares, J. (2010). Genetic resources and breeding of guava (Psidium guajava L.) in Cuba. Biotecnología Aplicada, 27(3), 238-240.

Rueda, F. D. M. N. (2005). Guava (Psidium guajava L.) fruit phytochemicals, antioxidant properties and overall quality as influenced by postharvest treatments (Doctoral dissertation). University of Florida, Gainesville.

Sahoo, N. R., Panda, M. K., Bal, L. M., Pal, U. S., \& Sahoo, D. (2015). Comparative study of MAP and shrink wrap packaging techniques for shelf life extension of fresh guava. Scientia Horticulturae, 182, 1-7. http://dx.doi.org/10.1016/j.scienta.2014.10.029.

Sandhu, K. S., Singh, M., \& Ahluwalia, P. (2001). Studies on processing of guava into pulp and guava leather. Journal of Food Science and Technology, 38(6), 622-624.

Santos, W. N. L., Silva Sauthier, M. C., Santos, A. M. P., Andrade Santana, D., Almeida Azevedo, R. S., \& Cruz Caldas, J. (2017). Simultaneous determination of 13 phenolic bioactive compounds in guava (Psidium guajava L.) by HPLC-PAD with evaluation using PCA and Neural Network Analysis (NNA). Microchemical Journal, 133, 583-592. http://dx.doi.org/10.1016/j.microc.2017.04.029.

Shetgar, S., Kemparaj, U., Chavan, S., \& Patel, R. (2017). Effect of fresh fruit juices on salivary $\mathrm{pH}$ : a randomized controlled trial. International Journal of Oral Health \& Medical Research, 3(5), 28-32.

Sinha, M., \& Sinha, A. M. P. (2017). Value addition of guava cheese cv. Allahabad safeda by medicinal herbs. Journal of Pharmacognosy \& Phytochemistry, 6(6), 856-859.

Soares, F. D., Pereira, T., Maio Marques, M. O., \& Monteiro, A. R. (2007). Volatile and non-volatile chemical composition of the white guava fruit (Psidium guajava) at different stages of maturity. Food Chemistry, 100(1), 15-21. http://dx.doi.org/10.1016/j. foodchem.2005.07.061.

Steel, R. G. D., Torrie, J. H., \& Dickey, D. A. (1997). Principles and procedures of statistics: a biometrical approach ( ${ }^{\text {rd }} \mathrm{ed}$.). New York: McGraw Hill Co.

Tanwar, B., Andallu, B., \& Chandel, S. (2014). Influence of processing on physicochemical and nutritional composition of Psidium Guajava L. (Guava) products. International Journal of Agriculture and Food science. Technology, 5(2), 47-54.

Uddin, M. S., Hawlader, M. N. A., Ding, L., \& Mujumdar, A. S. (2002). Degradation of ascorbic acid in dried guava during storage. Journal of Food Engineering, 51(1), 21-26. http://dx.doi.org/10.1016/S02608774(01)00031-0.

Ulhaq, I., Sajjad, M., Khan, S. A., Jaskani, M. J., \& Ullah, Z. (2013). Occurrence of guava anthracnose in Punjab (Pakistan) and its integrated management. Pakistan Journal of Agricultural Sciences, 50(4), 707-710.

Upadhyay, R., Dass, J. F. P., Chauhan, A. K., Yadav, P., Singh, M., \& Singh, R. B. (2019). Guava enriched functional foods: therapeutic potentials and technological challenges. In R. Watson, R. Singh \& 
T. Takahashi (Eds.), The role of functional food security in global health (pp. 365-378). New York: Academic Press.

Usman, M., Butt, M., \& Fatima, B. (2012). Enhanced in vitro multiple shoot induction in elite Pakistani guava cultivars for efficient clonal plant multiplication. African Journal of Biotechnology, 11(44), 10182-19187.

Verma, M., Rai, G. K., \& Kaur, D. (2018). Effect of extraction solvents on phenolic content and antioxidant activities of Indian gooseberry and guava. International Food Research Journal, 25(2), 762-768.

Waldron, K. W., Parker, M. L., \& Smith, A. C. (2003). Plant cell walls and food quality. Comprehensive Reviews in Food Science and Food Safety, 2(4), 128-146. http://dx.doi.org/10.1111/j.1541-4337.2003. tb00019.x.
White, P. J., \& Broadley, M. R. (2009). Biofortification of crops with seven mineral elements often lacking in human diets-iron, zinc, copper, calcium, magnesium, selenium and iodine. The New Phytologist, 182(1), 49-84. http://dx.doi.org/10.1111/j.1469-8137.2008.02738.x. PMid:19192191.

World Health Organization - WHO. (1996). Trace elements in human nutrition and health. Geneva: WHO.

Yahia, E. M. (2018). Fruits and vegetable phytochemicals: chemistry and human health (pp. 1067-1076). Wiley: Hoboken.

Yusof, S. (2003). Guavas. In B. Caballero, P. Finglas \& L. Trugo. Encyclopedia of food sciences and nutrition (pp. 2985-2992). New York: Academic Press. 